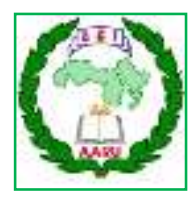

Arab Univ. J. Agric. Sci., Ain Shams Univ., Cairo, Egypt

29(1), 315 - 327, 2021

Website: http://ajs.journals.ekb.eg

DOI: 10.21608/ajs.2021.50511.1302

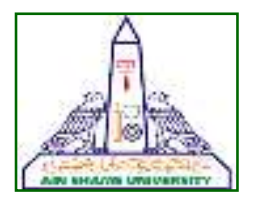

315

\title{
Improvement of Fungal Phytase Production and Its In-vitro Application in Ruminant Nutrition
}

Noha A Hassaan ${ }^{1 *}$, Abd El-Nasser A Khattab ${ }^{2}$, Mahmoud M Khorshed ${ }^{3}$, Nasr E El-Bordeny ${ }^{3}$, Abdelmegid A Abedo ${ }^{1}$, Mohsen M Shoukry ${ }^{1}$

1- Animal Production Dept, National Research Centre, Dokki, Giza, 12311, Egypt

2- Genetics and Cytology Dept, National Research Centre, Dokki, Giza, 12311, Egypt

3- Animal Production Dept, Fac of Agric, Ain Shams Univ, P.O. Box 68 Hadayek Shoubra, 11241, Cairo, Egypt

*Corresponding author: noha a h@hotmail.com

Received 24 November, 2020

Accepted 22 March, 2021

\begin{abstract}
Various fungal genotypes (Aspergillus niger NRRL 3135 (AN1), Aspergillus niger NRRL 326 (AN26), Aspergillus terrus F2-Kh (AT) and Mucor racemosus NRRL 3639 (MI)) were studied for their ability to produce phytase and improve the produced enzyme by ethyl-methane sulfonate (EMS) mutagenesis. AN1 showed the highest phytase activity on phytase screening medium supplemented with glucose (PSMG) after 8 days of incubation (reached $1875.40 \mathrm{IU} / \mathrm{mL}$ ). The phytase activity of AN1 increased with increasing incubation time and the highest value was achieved at 12 days of incubation $(2859.33 \mathrm{IU} / \mathrm{mL})$. The exposure of AN1 spore suspension to $200 \mathrm{mM}$ of EMS for different times enhanced the phytase activity and that mutant $20 \mathrm{Mn}$ exhibited the highest phytase activity (reached $4520.5 \mathrm{IU} / \mathrm{mL}$ ) therefore it was chosen for the next experiment. An in-vitro gas production procedure was carried out to evaluate the impact of using various amounts of laboratory produced phytase (PE) compared with commercial phytase (Axtra ${ }^{\circledR}$ PHY) on nutrients availability of ruminant's ration. Six levels $(0,400,800,1200,1600$ and 2000 IU phytase ${ }^{-1} \mathrm{Kg}$ dry matter) of phytase enzyme were evaluated with tested ration consisted of
\end{abstract}

$40 \%$ berseem hay (BH) and $60 \%$ concentrate feed mixture (CFM). In-vitro dry and organic matter degradability (IVDMD and IVOMD), total gas production (GP), short chain fatty acids (SCFA's) and inorganic phosphorus $\left(\mathrm{P}_{\mathrm{i}}\right)$ concentration were improved significantly $(\mathrm{P}<0.05)$ by phytase addition from the two sources of phytase and the highest significant $(\mathrm{P}<0.05)$ values achieved at the level of 1200 IU. Results suggest that phytase activity was influenced by exposure to EMS mutagen compared to the wild type. Also, the produced enzyme source has the ability to improve the utilization efficiency of phytate diets as evidenced by the significant $(\mathrm{P}<0.05)$ increase in all tested parameters compared to the commercial source.

Keywords: EMS-mutagenesis, Gasproduction, In-vitro, Phytase

\section{Introduction}

About $90 \%$ of the world's harvested area is cultivated with grains, legumes and oilseed crops. Thus they consider as the main nutrients source for the animal kingdom. An essential component of these crops is phytic acid (myoinositol hexakisphosphate), also known as phytate. In forage, two-thirds of phosphorus 
$(\mathrm{P})$ is found as organic $\mathrm{P}$ (phytate) and only one-third as digestible inorganic P. Phytate is an anhydrous reserve form of phosphate representing more than $80 \%$ of the total $\mathrm{P}$ in grains and legumes (Alexandra et al 2004). Phytate contains a high phosphate level which causes a high negative charge over a large range of $\mathrm{pH}$ therefore it works as an antinutritional factor (Singh 2008).

Because of the great importance of phytic acid hydrolysis, a specific class of enzymes hydrolyzing phytic acid (Ins $\mathrm{P}_{6}$ ) has been developed (the phytases). Phytase (Ins $\mathrm{P}_{6}$ phosphohydrolase) is the primary enzyme responsible for Ins $\mathrm{P}_{6}$ hydrolysis to inositol polyphosphates and inorganic monophosphate (Oh et al 2004). It can be located in bacteria, yeast, fungi, plants and animals. Howeover, the activity of phytase in microorganisms has been commonly located in fungi, especially, Aspergillus species. The genus Aspergillus (A. niger in specific) remains to be prefered for phytase production. This is not only because its generally recognized as safe (GRAS) status, but also because its big secretory possibility and the deep understanding about its growth cultivation (Shivanna and Govindarajulu 2009). Phytase production from fungi could be achieved using several methods and the method selection could depend upon the microorganism and the substrate to be used (Parekh et al 2000). However, the production level of naturally active strains is usually small for trading use. Thus, the success of any production method is reliant on discovering a convenient microorganism and enhancing its productivity if required. Mutagenesis and genetic recombination are the traditional ways that were used for strain enhancement (Punt et al 2002).

Recently, the report "Global Markets for Enzymes in Industrial Applications" by the BCC research (Sep. 2018) announced that the global industrial enzymes market should reach $\$ 7.0$ billion by 2023 from $\$ 5.5$ billion in 2018 at a compound annual growth rate (CAGR) of $4.9 \%$ for the period 2018-2023. According to this report, the animal feed enzyme industry is estimated to reach its fastest growth rate in growing markets. However, even though phytase addition efficiently enhances nutritional value while declining $P$ waste. The high cost of the phytase production reduces its commercial use, which required the ability to produce the enzyme economically. Therefore, the use of agro-industrial by-products for enzymes production, such as phytase, provids the dual benefit of given an added value to the feed ingredients and prevents $P$ pollution from farm manure. Moreover, the local production of such an important enzyme may encourage our self-reliance and reduce the cost of importation in Egypt.

For all reasons that mentioned above, two experiments were carried out in this study to: 1) screen various fungal strains for their phytase production ability under the optimum fermentation conditions to determine which one is the best producer of extracellular phytase, 2) improve microbial phytase production from the highest producing strain by ethyl-methane sulfonate (EMS) mutagenesis, 3) evaluate the potential use of various concentrations of laboratory produced phytase enzyme (PE) for improving in-vitro nutrients degradability of lactating animal ration compared with different levels of commercial phytase enzyme (Axtra ${ }^{\circledR}$ PHY) to decide the most effective level of phytase supplementation.

\section{Materials and Methods}

\subsection{Laboratory microbial phytase production trials}

\subsubsection{Microbial strains, media and inoculum preparation}

Aspergillus niger (syn. A. ficuum) NRRL 3135 (AN1), Aspergillus niger NRRL 326 (AN26), Aspergillus terrus F2-Kh (AT) (GenBank accession number MH997666) and Mucor racemosus NRRL 3639 (MI) were selected for screening their phytase production ability. The above fungal strains were obtained from Applied Microbial Genetics Lab., Genetics and Cytology Dept., National Research Centre, Cairo, Egypt and maintained 
on potato dextrose agar (PDA) slants.

For the preparation of active fungal inoculum; fungal strains were incubated for 7 days at $30^{\circ} \mathrm{C}$ on solid slant medium containing per liter: $3 \mathrm{~g} \mathrm{NaNO}_{3}, 1 \mathrm{~g} \mathrm{~K} \mathrm{HPO}_{4}, 30 \mathrm{~g}$ sucrose, $0.01 \mathrm{~g} \mathrm{FeSO}_{4} .7 \mathrm{H}_{2} \mathrm{O}, 0.5 \mathrm{~g} \mathrm{MgSO}_{4} .7 \mathrm{H}_{2} \mathrm{O}, 2 \mathrm{~g}$ casamino acid, $2 \mathrm{~g}$ yeast extract and $15 \mathrm{~g}$ agar. After incubation, $5 \mathrm{ml}$ of spore collection solution ( $1 \mathrm{~g}$ Tween 80 and $1 \mathrm{~g} \mathrm{CaCO}_{3}$ per liter) was added with scraping the culture surface for 2-3 min. using a sterile inoculating needle under aseptic condition (Kim et al 1999).

\subsubsection{Screening for phytase-producing fungi}

Submerged fermentation $(\mathrm{SmF})$ was used to investigate the effect of different phytase screening media (PSM) and incubation periods (2, 4 and 8 days) on phytase production by various fungal genotypes (AN1, AN26, AT and MI). The used fermentation media had the following composition ( $\mathrm{g} / \mathrm{l})$ : dextrin, 50; $\mathrm{NaNo}_{3}, \quad 8.6 ; \mathrm{KCl}, \quad 0.5 ; \quad \mathrm{KH}_{2} \mathrm{PO}_{4}, \quad 0.04$; $\mathrm{FeSO}_{4} .7 \mathrm{H}_{2} \mathrm{O}, 0.1 ; \quad \mathrm{MgSO}_{4} .7 \mathrm{H}_{2} \mathrm{O}, 0.5$ and glucose, 52 or sucrose, 25 for PSMG and PSMS, respectively (Shieh and Ware 1968). About $100 \mathrm{ml}$ growth media were transferred into $250 \mathrm{ml}$ conical flasks and autoclaved at $121{ }^{\circ} \mathrm{C}$ for $20 \mathrm{~min}$. After cooling, the media were inoculated with $1 \%(\mathrm{v} / \mathrm{v})$ of spore suspension and incubated in a rotary shaker $(120 \mathrm{rpm})$ at $30^{\circ} \mathrm{C}$ for 2,4 and 8 days. After centrifugation, the supernatant was determined for phytase activity.

A complementary experiment was designed to examine the impact of various incubation times on phytase enzyme production by the most efficient fungal strain at selected medium. Therefore, fungal spores were transferred into $250 \mathrm{ml}$ conical flasks each containing $100 \mathrm{ml}$ of selected medium with wheat bran (10\%). Cultures were incubated on a rotary shaker $(120 \mathrm{rpm})$ at $30^{\circ} \mathrm{C}$ for $2,4,6,8,10,12$ and 14 days and after centrifugation, the supernatant was evaluated for phytase activity.

\subsubsection{Mutagenesis of fungal strain by ethyl- methane sulfonate (EMS)}

The fungal spore suspension $(5 \mathrm{ml})$ was transferred to sterile tube containing sodium phosphate buffer $(0.1 \mathrm{M}, \mathrm{pH} 7.0)$ and treated with EMS $(200 \mathrm{mM})$. After different time intervals (20, 40 and 60 minutes), EMS treated spores were washed three times with sterilized sodium thiosulfate buffer (5\%), to take off any traces of EMS-mutagen, and centrifuged for 2 min at $13000 \mathrm{rpm}$ (Asia et al 2018).

Obtained mutants were chosen by spreading EMS-treated spores on Petri plates containing $100 \mathrm{ml}$ of phytase screening medium (PSM) supplemented with $2 \%$ agar, $0.1 \%$ Triton X 100 and heavy metals $(250 \mathrm{ppm}$ cobalt or $500 \mathrm{ppm}$ manganese) according to Khattab and Abd-El Salam (2012). Control without mutation (wild type) was also plated, and then all plates were incubated for 2-3 days at $30^{\circ} \mathrm{C}$. The selection was determined by the observation of heavy metal resistance, survival percentage was estimated. Mutants were assured for the production of phytase by using the selected medium under SmF with wheat bran $(10 \%)$ as described before. Cultures were incubated on a rotary shaker at $30^{\circ} \mathrm{C}(120 \mathrm{rpm})$ for 12 days. After incubation, phytase activity was evaluated according to Gulati et al. (2007).

\subsubsection{Enzyme sources}

Produced enzyme (PE): Laboratory produced phytase enzyme from the most efficient fungus mutant. Each gram contains 2000 IU of phytase.

Axtra ${ }^{\circledR}$ PHY: A commercial enzyme produced by Danisco Animal Nutrition, UK, and distributed by Multi Vita Co. for Animal Nutrition, Second Industrial, 6 October Governorate, Giza, Egypt. This phytase feed enzyme, is extracted from a Buttiauxella species bacterium and is expressed in a Trichoderma reesei fungus and including 6000 unit/g of phytase. 


\subsubsection{Enzyme assay}

The phytase activities for PE and Axtra ${ }^{\circledR}$ PHY were estimated according to Gulati et al. (2007). Enzyme activity was expressed in international units (IU). One unit of phytase activity was known as the amount of enzyme that required to release $1 \mu \mathrm{mol}$ of $\mathrm{P}_{\mathrm{i}}$ per min under the assay conditions.

\subsection{The in-vitro trials}

\subsubsection{Experimental ration and treatments}

The tested ration was consisted of $40 \%$ berseem hay $(\mathrm{BH})$ and $60 \%$ concentrate feed mixture (CFM). The CFM was containing $52.2 \%$ yellow corn, $21 \%$ wheat bran, $12.5 \%$ undecorticated cottonseed meal, $12.5 \%$ soybean meal, $0.5 \%$ sodium chloride, $0.8 \%$ limestone, and $0.5 \%$ minerals and vitamins complex. Two sources of phytase enzyme were used (Axtra ${ }^{\circledR} \mathrm{PHY}$ and PE) at 6 different levels $(0,400,800,1200,1600$ and $2000 \mathrm{IU}$ phytase ${ }^{-1} \mathrm{Kg}$ dry matter), samples were incubated for $24 \mathrm{hr}$.

\subsubsection{In-vitro gas production technique}

A $400 \mathrm{mg}$ of experimental ration consisted of $160 \mathrm{mg} \mathrm{BH}$ and $240 \mathrm{mg}$ CFM for each treatment was accurately weighed into $125 \mathrm{ml}$ glass bottles and supplemented with solutions of Axtra ${ }^{\circledR} \mathrm{PHY}$ and PE at 6 various levels as described above. Enzyme solutions were added onto the samples immediately before the supplementation of buffer and rumen liquor. Rumen fluid was taken from the rumen of slaughtered steers, fed $\mathrm{BH}$ and CFM, and moved directly to the laboratory in a prewarmed thermos flask. Then it was strained through 4 layers of cheese-cloth, flushed with $\mathrm{CO}_{2}$, transferred to the McDougall's buffer solution (McDougall 1948) (1:4 v/v), and mixed. Every bottle was incubated with $40 \mathrm{ml}$ of diluted rumen fluid, flushed with $\mathrm{CO}_{2}$, sealed with stoppers and maintained in the incubator at $39^{\circ} \mathrm{C}$ for $24 \mathrm{hr}$. After the end of incubation, contents of each bottle were filtered filter bag 25-micron porosity (ANKOM-USA), and then rumen $\mathrm{pH}$ was determined by a $\mathrm{pH}$-meter. Bags residues were oven-dried at $70{ }^{\circ} \mathrm{C}$ for $48 \mathrm{hr}$ to determine the in-vitro dry and organic matter degradability (IVDMD and IVOMD). The overall volume of gas production (GP) was estimated using Hohenheim Syringe as shown by NavarroVilla et al (2011). Inorganic phosphorus $\left(\mathrm{P}_{\mathrm{i}}\right)$ concentration was determined according to AOAC (2000). Also, short chain fatty acids (SCFA's) content was calculated as stated by Makkar (2005):

$$
\text { SCFA }(\mathrm{mmol})=0.0222 \text { Gas }-0.00425
$$

Where: Gas = Gas production at $24 \mathrm{hr}$ incubation $(\mathrm{ml} / 200 \mathrm{mg} \mathrm{DM})$

\subsubsection{Statistical analysis}

Collected data were statistically analyzed by SPSS (2008). Two way ANOVA procedure was applied in the second experiment to evaluate the effect of phytase addition from various sources (Axtra ${ } \mathrm{PHY}$ and $\mathrm{PE}$ ) at different levels $(0,400,800,1200,1600$ and 2000 IU phytase ${ }^{-1} \mathrm{Kg}$ dry matter) on IVDMD, IVOMD, $\mathrm{P}_{\mathrm{i}}$, GP, SCFA's and $\mathrm{pH}$ according to the following model:

$$
Y_{i j k}=\mu+S_{i}+L_{j}+S L_{i j}+e_{i j k}
$$

Where:

$\mathrm{Y}_{\mathrm{ijk}}=$ any value from the overall population $\mu=$ overall mean.

$S_{i}=$ effect of the $i^{\text {th }}$ different phytase enzyme sources.

$\mathrm{L}_{\mathrm{j}}=$ effect of the $\mathrm{j}^{\text {th }}$ different phytase enzyme levels.

$\mathrm{SL}_{\mathrm{ij}}=$ effect of the interaction between the $\mathrm{i}^{\mathrm{th}}$ phytase enzyme sources and the $\mathrm{j}^{\text {th }}$ phytase enzyme levels.

$\mathrm{e}_{\mathrm{ijk}}=$ the random error associated with the $\mathrm{k}^{\text {th }}$ individual receiving the $i^{\text {th }}$ phytase enzyme sources and the $\mathrm{j}^{\text {th }}$ phytase enzyme levels. 


\section{Results and Discussion}

\subsection{Laboratory microbial phytase production trials}

\subsubsection{Screening for phytase-producing fungi}

Results in Fig 1 illustrated the effect of different fermentation media and incubation periods on phytase enzyme production from different fungal genotypes. By using PSMG medium, increasing the incubation period from 2 to 8 days increased the phytase activity of all fungal genotypes. However, AN1 showed the highest phytase activity after 8 days of incubation (recorded $1875.40 \mathrm{IU} / \mathrm{mL}$ ) compared with the phytase activity from AN26; MI and AT (recorded 404.72; 474.83 and $485.38 \mathrm{IU} / \mathrm{mL}$, respectively). Similar trend was observed with PSMS medium, whereas phytase activity obtained at PSMS medium after 8 days of incubation recorded 1735.4; 556.84; 513.19 and $434.48 \mathrm{IU} / \mathrm{mL}$ from AN1; MI; AT and AN26, respectively. It was observed obviously that the highest phytase production was obtained at the PSMG medium compared to the PSMS medium, therefore AN1 and PSMG medium were selected for further work. The effect of different incubation periods on AN1 phytase enzyme production at PSMG medium is presented in Fig 2.

Results showed that phytase activity of AN1 at PSMG medium was increasing as the incubation period increased and it reached to the highest value at 12 days of incubation $(2859.33 \mathrm{IU} / \mathrm{mL})$, then it was decreased by increasing the incubation time to 14 days $(2693.25 \mathrm{IU} / \mathrm{mL})$. These results are in line with previous outcomes mentioned by some other researchers (Ullah and Phillippy 1994; Wodzinski and Ullah 1996; Mullaney et al 2002) that investigated the Aspergillus niger (ficuum) NRRL 3135 strain efficiency's for extracellular phytase production compared to other strains as they were impressed with its phytase activity.

\subsubsection{Induction of overproducing phytase mutants}

Based on the mentioned results, Aspergillus niger (ficuum) NRRL 3135 (AN1) was chosen for the further mutation studies because it exhibited the highest phytase activity. Number of the colonies (cfu/ml) and survival percentages following exposure periods of AN1 to ethyl-methane sulfonate (EMS) mutagenesis are given in Table 1. The results showed that increasing the exposure time to EMS mutagenesis from 20 to 40 min decreased the survival percentages of AN1 from 59.43\% to $35.38 \%$. Moreover, the survival percentages continued to be decreased as the exposure time to EMS mutagenesis increased to $60 \mathrm{~min}$. giving $22.17 \%$.

Data in Table 2 represents the phytase activity of mutants obtained from exposure of AN1 to EMS mutagen for 20, 40 and 60 minutes. The results showed that phytase activity was influenced by exposure to EMS mutagen compared to the wild type (WT) at all exposure times. Among different tested mutants, mutant $20 \mathrm{Mn}$ exhibited the highest phytase activity (recorded $4520.5 \mathrm{IU} / \mathrm{mL}$ ) compared with other mutants at all exposure times (20, 40 and $60 \mathrm{~min}$.).

Phytases are gotten for the most part from genetically improved strains because the wildtype ones produce little protein comparative with commercial request. The enhancement in enzyme yield that can be accomplished by mutating a single gene (once or consistently) is restricted, hence in a strain enhancement program a progression of mutagenic operators is utilized (Parekh et al 2000). Chelius and Wodzinski (1994) built up a strain enhancement plan as ultraviolet radiation was the main mutagen applied to increment phytase creation by A. niger NRRL 3135. Shah et al (2009) used a mix of chemical (EMS) and physical mutagen to obtain superior secretory strains of A. niger NCIM 563 for phytase creation. Recently, Mehmood et al (2019) 


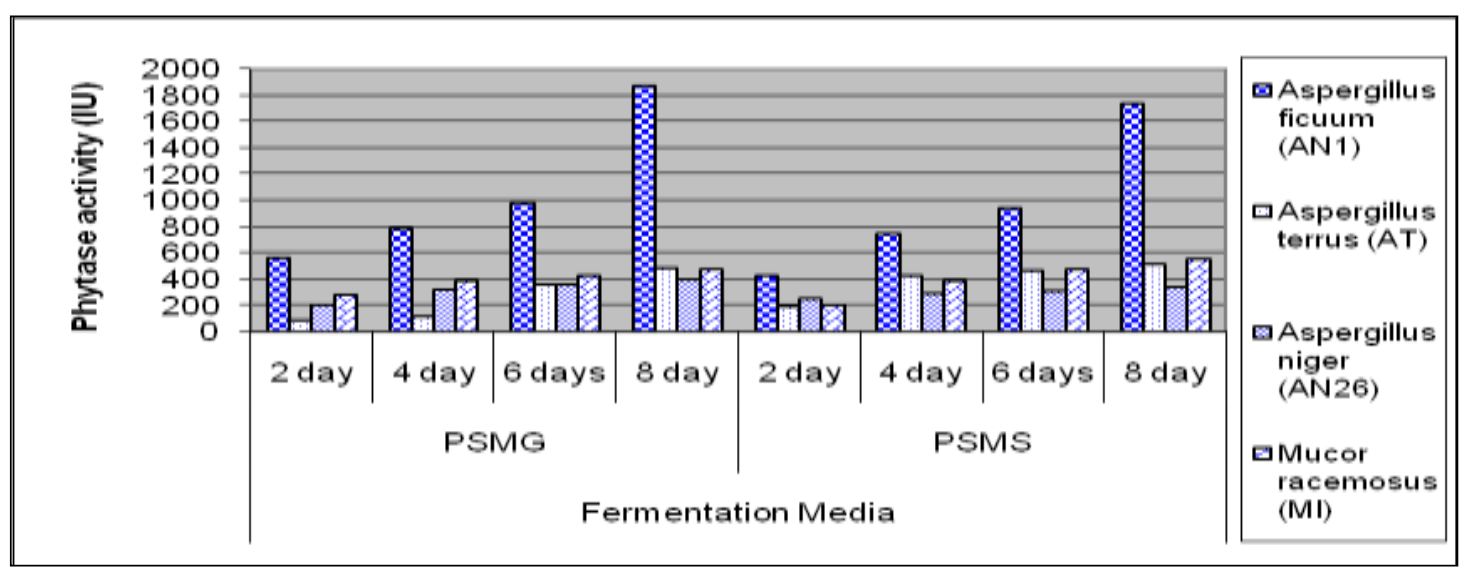

Fig 1. Effect of different fermentation media and incubation periods on phytase production (IU) of different fungal genotypes

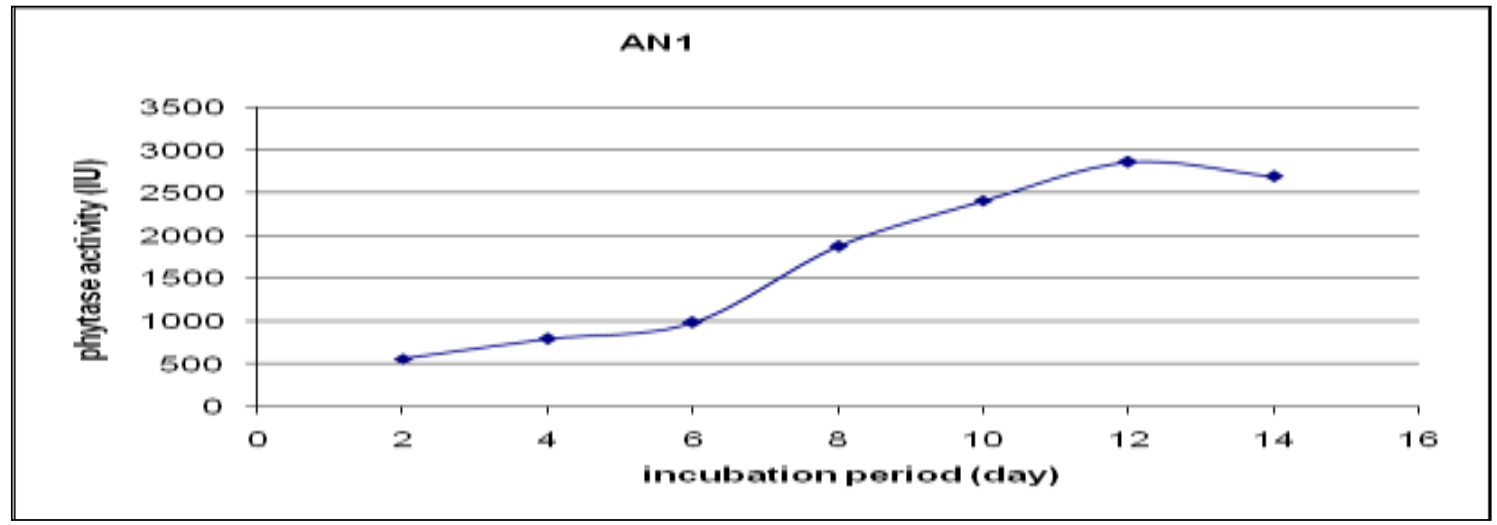

Fig 2. Effect of different incubation periods on phytase production of Aspergillus ficuum NRRL 3135 (AN1)

Table 1. Number of the colonies (cfu/ml) and survival percentages following exposure periods of Aspergillus niger (ficuum) NRRL 3135 to ethyl-methane sulfonate (EMS) mutagenesis

\begin{tabular}{|c|c|c|}
\hline Treatment (min.) & No. of colonies & Survival \% \\
\hline 0 & 212 & 100 \\
\hline 20 & 126 & 59.43 \\
\hline 40 & 75 & 35.38 \\
\hline 60 & 47 & 22.17 \\
\hline
\end{tabular}



Application in Ruminant Nutrition

Table 2. Phytase activity of mutants obtained from exposure of Aspergillus niger NRRL 3135 to ethyl-methane sulfonate mutagenesis for 20, 40, and 60 minutes

\begin{tabular}{|c|c|c|}
\hline Mutant No. & Phytase Activity (IU/mL) & \% to Wild Type (WT) \\
\hline Wild Type & 2859.3 & 100 \\
\hline Mutant 20 Mn & 4520.5 & 158.1 \\
\hline Mutant 20 Co & 3347.8 & 117.08 \\
\hline Mutant 40 Mn & 3443.1 & 120.4 \\
\hline Mutant 40 Co & 3727.5 & 130.36 \\
\hline Mutant 60 Mn & 3687.8 & 129.0 \\
\hline Mutant 60 Co & 2644.1 & 92.47 \\
\hline
\end{tabular}

Where: Mn: manganese and Co: cobalt

enhanced S. thermophile strain ST20 utilizing chemical and physical mutagens for improved phytase productivity. Authors utilized EMS and gamma rays mutagenesis to improve the phytase activity, they revealed that the mutants created through EMS showed more noteworthy capability of phytase creation when contrasted with the parent strain.

\subsection{In-vitro trials}

\subsubsection{Dry matter and organic matter degradability}

The effect of phytase supplementation from various sources (Axtra ${ }^{\circledR} \mathrm{PHY}$ and PE) and the effect of different phytase enzyme levels $(0$, 400, 800, 1200, 1600 and $2000 \mathrm{IU}_{\text {phytase }}{ }^{-1} \mathrm{Kg}$ dry matter) on IVDMD, IVOMD, $\mathrm{P}_{\mathrm{i}}$, GP, SCFA and $\mathrm{pH}$ of the experimental ration after $24 \mathrm{hr}$ of incubation are presented in Table 3 . Dry and organic matter degradability increased significantly $(\mathrm{P}<0.05)$ with phytase addition from the two sources of phytase. However, phytase supplementation from PE source significantly $(\mathrm{P}<0.05)$ improved IVDMD and IVOMD values compared to Axtra®PHY source. Increasing the phytase level from both enzyme sources increased $(\mathrm{P}<0.05)$ the IVDMD and IVOMD and the highest significant $(\mathrm{P}<0.05)$ value achieved at the level of $1200 \mathrm{IU}$, then IVDMD and IVOMD values decreased significantly $(\mathrm{P}<0.05)$ by increasing the level of phytase from 1200 IU to 2000 IU.

Our results are consistent with those of Bravo et al (2003) where they noticed that supplementing 2000 IU of fungal phytase (Nathuphos $\left.{ }^{\circledR}, \mathrm{BASF}\right)$ to the formaldehydetreated soybean diet slightly increased DM digestibility in sheep. Allam et al (2014) carried out a trials to study the effect of phytase addition on in-vitro degradation of feed ingredients. Dry matter and organic matter disappearance were estimated for 4 ingredients that consisted of high phytate P. Five levels $(0$, $500,1000,1500$ and $2000 \mathrm{IU} / \mathrm{Kg} \mathrm{DM}$ ) of phytase (Nutrase P 500®) were used. The authors concluded that addition of phytase at $500 \mathrm{IU} / \mathrm{Kg} \mathrm{DM}$ revealed the highest value of IVDMD and IVOMD. Also, Azzaz et al (2019) used an in-vitro batch culture technique to study the impact of xylanase and phytase addition at various levels $(0,1,2$ and $3 \mathrm{~g} / \mathrm{kg}$ $\mathrm{DM}$ ) on rumen characteristics. They found that phytase and xylanase supplementation increased IVDMD and IVOMD.

These positive effects of phytase supplementation on IVDMD and IVOMD may be due to that enzymes were able to digest complicate substrate to simpler compounds which might change the surface structure of substrates, making them more accessible to ruminal microbial degradation and allowing a faster ruminal colonization and fermentation 
as suggested by Yang et al (1999) and Colombatto et al (2003). Furthermore, Durand and Komisarczuk (1987) observed that the rumen ecosystem appears to be $\mathrm{P}$ dependent for the degradation of cell walls. Therefore, maintaining a stable rumen $\mathrm{P}_{\mathrm{i}}$ concentration appears necessary to acheive suitable diet digetion. Moreover, the difference between the two sources of phytase in their effect on IVDMD and IVOMD values may be due to the differences in their composition.

\subsubsection{Inorganic phosphorus concentration}

Data in Table 3 indicated an increase $(\mathrm{P}<0.05)$ in $\mathrm{P}_{\mathrm{i}}$ concentration with phytase supplementation after $24 \mathrm{hrs}$. of incubation. Furthermore, the PE source of phytase had a significant $(\mathrm{P}<0.05)$ effect on $\mathrm{P}_{\mathrm{i}}$ value compared to Axtra®PHY source. Regardless the source of phytase, increasing the level of addition from both enzyme sources significantly $\quad(\mathrm{P}<0.05) \quad$ improved $\quad \mathrm{P}_{\mathrm{i}}$ concentration until it reached its highest value at level of $1200 \mathrm{IU}$, then decreased $(\mathrm{P}<0.05)$ by increasing the phytase concentration to 2000 IU.

Our outcomes are in good agreement with previous finding of Shanklin (2001) who found that supplentation of phytase (1000 IU) to the diets of lambs fed with organic $\mathrm{P}$ (cottonseed meal diets) resulted in more $\mathrm{P}_{\mathrm{i}}$ in the ruminal fluid. Similarly, Bravo et al (2002) illustrated that both phytase addition (2000 IU) and the increases in concentrate feed mixture level to $70 \%$ motivate $\mathrm{P}$ solubilization in the rumen of lactating goats. Brask-Pedersen et al (2011) indicated that exogenous phytase can enhance ruminal inositol phosphate degradation and thereby increase $P$ availability and permit a lower allocation of $\mathrm{P}$ in the diet.

The increasing of $P_{i}$ values with phytase supplementation may be explained by the fact that phytases (Ins $\mathrm{P}_{6}$ phosphohydrolase) are the primary enzymes responsible for the hydrolysis of phytate to inorganic phosphate (Rosenfelder-Kuon et al 2019; Jatuwong et al 2020).

\subsubsection{Gas production and SCFA's concentration}

Results presented in Table 3 highlighted that phytase addition enhanced $(\mathrm{P}<0.05)$ the overall volume of GP and SCFA's concentrations after $24 \mathrm{hrs}$. of incubation. Phytase supplementation from PE source significantly $(\mathrm{P}<0.05)$ improved $\mathrm{GP}$ and SCFA's concentration compared to Axtra ${ }^{\circledR}$ PHY source. However, increasing the level of supplementation had a significant $(\mathrm{P}<0.05)$ effect on GP and SCFA's values and the highest values were recorded at a level of 1200 $\mathrm{IU}^{-1} \mathrm{Kg}$ DM. This result confirms with previous finding of Komisarczuk et al (1987) who stated that reducing $\mathrm{Pi}$ concentrations caused a significant reductions in total volatile fatty acids (TVFA's) production, accompanied by a rise in $\mathrm{pH}$ value. Sampath et al (1995) reported that when the concentrate feeds was mixed with hay, the total GP and the rate of GP improved. Also, Salem et al (2013) revealed that the addition of enzymes increased SCFA's concentration. Nasser et al (2010) observed that increasing $\mathrm{P}$ level improved the cumulative volume of GP. Azzaz et al (2019) found that xylanase and phytase addition at various levels $\left(0,1,2\right.$ and $3 \mathrm{~g}^{-1} \mathrm{~kg}$ dry matter) increased ruminal $\mathrm{NH}_{3}-\mathrm{N}$ and TVFA's concentrations, while it did not affect the volume of total gas production.

\subsubsection{Rumen fluid pH}

Data in Table 3 illustrated that phytase supplementation with PE source led to decrease $(\mathrm{P}<0.05) \mathrm{pH}$ values compared to Axtra ${ }^{\circledR}$ PHY source after $24 \mathrm{hr}$ of incubation. However, increasing the level of addition from both enzyme sources significantly $(\mathrm{P}<0.05)$ decreased $\mathrm{pH}$ values until it reached its lowest value at level of $1200 \mathrm{IU}$, then $\mathrm{pH}$ values increased $(\mathrm{P}<0.05)$ by increasing the level of phytase from 1200 IU to 2000 IU. These results may be due to that phytase supplementation increased the dry and organic matter degradability, the overall volume of GP, SCFA's and $\mathrm{P}_{\mathrm{i}}$ concentrations led to an 

Application in Ruminant Nutrition

Table 3. Effect of phytase source and level on in-vitro ruminal fermenation characteristics for the experimental raion

\begin{tabular}{|c|c|c|c|c|c|}
\hline \multirow[b]{2}{*}{ Item } & \multirow[b]{2}{*}{$\begin{array}{l}\text { Enzyme } \\
\text { levels IU }\end{array}$} & \multicolumn{2}{|c|}{ Enzyme sources } & \multirow{2}{*}{$\begin{array}{l}\text { Overall } \\
\text { mean }\end{array}$} & \multirow[b]{2}{*}{ SEM } \\
\hline & & $\begin{array}{c}\text { Commercial } \\
(\text { Axtra®PHY) }\end{array}$ & Produced & & \\
\hline \multirow{7}{*}{$\begin{array}{l}\text { In-vitro dry matter } \\
\text { degradability } \\
\text { (IVDMD, \%) }\end{array}$} & 0 & 44.07 & 44.07 & $44.07^{\mathrm{e}}$ & \\
\hline & 400 & 43.43 & 49.73 & $46.58^{\mathrm{d}}$ & \\
\hline & 800 & 44.72 & 51.62 & $48.17^{\mathrm{c}}$ & \\
\hline & 1200 & 53.90 & 54.52 & $54.20^{\mathrm{a}}$ & \\
\hline & 1600 & 48.29 & 51.07 & $49.68^{\mathrm{b}}$ & \\
\hline & 2000 & 46.11 & 47.75 & $46.93^{\mathrm{cd}}$ & \\
\hline & Overall mean & $46.75^{\mathrm{b}}$ & $49.79^{\mathrm{a}}$ & & 0.66 \\
\hline \multirow{7}{*}{$\begin{array}{l}\text { In-vitro organic matter } \\
\text { degradability } \\
\text { (IVOMD, \%) }\end{array}$} & 0 & 49.15 & 49.15 & $49.15^{\mathrm{e}}$ & \\
\hline & 400 & 48.17 & 54.81 & $51.49^{\mathrm{d}}$ & \\
\hline & 800 & 50.13 & 56.70 & $53.41^{\mathrm{c}}$ & \\
\hline & 1200 & 57.98 & 59.94 & $58.96^{\mathrm{a}}$ & \\
\hline & 1600 & 53.70 & 56.15 & $54.93^{\mathrm{b}}$ & \\
\hline & 2000 & 51.19 & 52.83 & $52.01^{\mathrm{cd}}$ & \\
\hline & Overall mean & $51.72^{\mathrm{b}}$ & $54.93^{\mathrm{a}}$ & & 0.65 \\
\hline \multirow{7}{*}{$\begin{array}{l}\text { Inorganic phosphorus } \\
\qquad\left(\mathrm{P}_{\mathrm{i}}, \mu \mathrm{g} / \mathrm{ml}\right)\end{array}$} & 0 & 228.1 & 228.1 & $228.1^{\mathrm{f}}$ & \\
\hline & 400 & 242.4 & 245.6 & $244.0^{\mathrm{c}}$ & \\
\hline & 800 & 249.5 & 253.1 & $251.3^{\mathrm{b}}$ & \\
\hline & 1200 & 254.7 & 256.0 & $255.3^{\mathrm{a}}$ & \\
\hline & 1600 & 238.3 & 234.7 & $236.5^{\mathrm{d}}$ & \\
\hline & 2000 & 229.4 & 234.3 & $231.8^{\mathrm{e}}$ & \\
\hline & Overall mean & $240.4^{\mathrm{b}}$ & $242.0^{\mathrm{a}}$ & & 1.72 \\
\hline \multirow{7}{*}{$\begin{array}{l}\text { Gas production } \\
(\mathrm{GP}, \mathrm{ml})\end{array}$} & 0 & 125.7 & 125.7 & $125.7^{\mathrm{e}}$ & \\
\hline & 400 & 130.0 & 133.0 & $131.5^{\mathrm{c}}$ & \\
\hline & 800 & 131.7 & 133.0 & $132.3^{\mathrm{b}}$ & \\
\hline & 1200 & 135.0 & 137.3 & $136.2^{\mathrm{a}}$ & \\
\hline & 1600 & 129.7 & 132.0 & $130.8^{c}$ & \\
\hline & 2000 & 127.0 & 128.0 & $127.5^{\mathrm{d}}$ & \\
\hline & Overall mean & $129.8^{\mathrm{b}}$ & $131.5^{\mathrm{a}}$ & & 0.62 \\
\hline \multirow{7}{*}{$\begin{array}{l}\text { Short chain fatty acids } \\
\quad \text { (SCFA's, mmol) }\end{array}$} & 0 & 1.39 & 1.39 & $1.39^{\mathrm{e}}$ & \\
\hline & 400 & 1.44 & 1.47 & $1.45^{\mathrm{bc}}$ & \\
\hline & 800 & 1.45 & 1.47 & $1.46^{\mathrm{b}}$ & \\
\hline & 1200 & 1.49 & 1.51 & $1.50^{\mathrm{a}}$ & \\
\hline & 1600 & 1.43 & 1.46 & $1.44^{\mathrm{bc}}$ & \\
\hline & 2000 & 1.40 & 1.41 & $1.41^{\mathrm{d}}$ & \\
\hline & Overall mean & $1.43^{\mathrm{b}}$ & $1.45^{\mathrm{a}}$ & & 0.01 \\
\hline \multirow{7}{*}{$\mathrm{pH}$} & 0 & 6.5 & 6.5 & $6.5^{\mathrm{a}}$ & \\
\hline & 400 & 6.2 & 6.0 & $6.1^{\mathrm{b}}$ & \\
\hline & 800 & 6.1 & 6.0 & $6.0^{c}$ & \\
\hline & 1200 & 5.9 & 5.8 & $5.9^{\mathrm{d}}$ & \\
\hline & 1600 & 6.0 & 5.9 & $6.0^{c}$ & \\
\hline & 2000 & 6.1 & 6.0 & $6.1^{\mathrm{b}}$ & \\
\hline & Overall mean & $6.1^{\mathrm{a}}$ & $6.0^{\mathrm{b}}$ & & 0.02 \\
\hline
\end{tabular}

\footnotetext{
"Means designated with the same letter in the same column are not significantly different at 0.05 level of probability. SEM: standard error of the means.
} 
improvement in rumen fermentation. Komisarczuk et al (1987) observed that reducing $\mathrm{P}_{\mathrm{i}}$ concentrations caused the total VFA's production to decrease and the $\mathrm{pH}$ value to rise.

\section{Conclusion}

It could be concluded that Aspergillus niger (ficuum) NRRL 3135 (AN1) exhibited the highest phytase activity at PSMG medium, and the best incubation period was 12 days. Moreover, data showed that phytase activity was influenced by exposure to EMS mutagen compared to the wild type culture at all exposure periods (20, 40 and $60 \mathrm{~min}$.). Among different tested mutants, mutant $20 \mathrm{Mn}$ exhibited the highest phytase activity (reached $4520.5 \mathrm{IU} / \mathrm{mL}$ ). Furthermore, results suggested that supplementation of phytase enzyme may enhance the utilization efficiency of high concentrate diets as evidenced by the significant $(\mathrm{P}<0.05)$ increase in IVDMD, IVOMD, GP, SCFA's, and $P_{i}$ concentration. Phytase supplementation from PE source significantly $(\mathrm{P}<0.05)$ improved all tested parameters compared to Axtra ${ }^{\circledR P H Y}$ source and the optimal enzyme level from both phytase sources was $1200 \mathrm{IU}^{-1} \mathrm{Kg}$ ration.

\section{References}

A.O.A.C. (2000) Association of Official Analytical Chemists, official Methods of Analysis. $17^{\text {th }}$ ed. Arlington, VA, USA.

Alexandra, EP; Buckland, T; Hing, K; Best, SM; Bonfield, W (2004) The structure of the bond between bone and porous silicon-substituted hydroxyapatite Bioceramic implants. Journal of Biomedical Materials Research Part A 8, 25-33.

Allam, SM; Sawsan, AM; Omer, HA; Rania, E; Farghaly, M; Noha, AH (2014) Effect of adding phytase to sheep rations on in vitro disappearance of dry matter and organic matter \& growth performance. Global Vet 13, 918-925.
Asia, L; Mohsin, I; Muhammad, A (2018) Ethyl methane sulfonate chemical mutagenesis of Bacillus subtilis for enhanced production of protease. Organic \& Medicinal Chem I J. 5, 555-664.

Azzaz, HH; Aboamer, AA; Alzahar H; Abdo MM; Murad, HA (2019) Effect of xylanase and phytase supplementation on goat's performance in early lactation. Pak J Biol Sci. 22, 265-272.

Brask-Pedersen, D.N; Glits $\varnothing$, LV; Skov, LK; Lund, P; Sehested, J (2011) Effect of exogenous phytase on feed inositol phosphate hydrolysis in an in vitro rumen fluid buffer system. Journal of Dairy Science 94, 951-959.

Bravo, D; Meschey, F; Bogaert, C; Sauvant, D (2002) Effects of fungal phytase addition, formaldehyde treatment and dietry concentrate content on ruminal phosphorus availability. Animal Feed Science and Technology 99, 7395.

Bravo, D; Sauvant, D; Bogaert, C; Meschy, F (2003) Quantitative aspects of phosphorus excretion in ruminants. Reprod Nutr Dev 43, 285-300.

Chelius, MK; Wodzinski, RJ (1994) Strain improvement of Aspergillus niger for phytase production. Appl Microbiol Biotechnol 41, 7983.

Colombatto, D; Mould, FL; Bhat, MK; Phipps, RH; Owen, E (2003) Influence of fibrolytic enzymes on the hydrolysis and fermentation of pure cellulose and xylan by mixed ruminal microorganisms in vitro. J Anim Sci 81, 10401045 .

Durand, M; Komisarczuk, S (1987) Influence of major minerals on rumen microbiota. $J$ Nutr 118, 249-260.

Gulati, HK; Chadha, BS; Saini, HS (2007) Production and characterization of thermostable alkaline phytase from Bacillus laevolacticus isolated from rhizosphere soil. J Ind Microbiol Biotechnol 34, 91-98. 
Jatuwong, K; Suwannarach, N; Kumla, J; Penkhrue, W; Kakumyan, P; Lumyong, S (2020) Bioprocess for production, characteristics, and biotechnological applications of fungal phytases. Frontiers in Microbiology 11, 118.

Khattab AA; Abd-El Salam IS (2012) Construction of new mutants of Mucor racemosus to improve progesterone biotransformation. Australian Journal of Basic and Applied Sciences 6, 356-363.

Kim Doo-Sang; Godber, JS; Kim, H (1999) Culture conditions for a new phytase-producing fungus. Biotechnology Letters 21, 1077 1081.

Komisarczuk, S; Merry, RJ; McAllan, AB (1987) Effect of different levels of phosphorus on rumen microbial fermentation and synthesis determined using a continuous culture technique. British Journal of Nutrition 57, 279290.

Makkar, HPS (2005) In vitro gas methods for evaluation of feeds containing phytochemicals. Animal Feed Science and Technology 123-124, pp.

291-302.

DOI:10.1016/j.anifeedsci.2005.06.003

McDougall, EI (1948) Studies on ruminant saliva. 1. The composition and output of sheep's saliva. Biochemical Journal 43, 99-109.

Mehmood, A; Baneen, U; Zaheer, A; Sajid, MW; Hussain, A; Saleem, S (2019) Physical and chemical mutagens improved Sporotrichum thermophile, strain ST20 for enhanced phytase activity. Saudi J. Biol. Sci., 26: 1485-1491.

Mullaney, EJ; Daly, CB; Kim, T; Porres, JM; Lei, XG; Sethumadhavan, K; Ullah, AH (2002) Site-directed mutagenesis of Aspergillus niger NRRL 3135 phytase at residue to enhance catalysis at $\mathrm{pH}$ 4.0. Biochemical and Biophysical Research Communications 297, 1016-1020.
Nasser, MEA; Sallam, SMA; Araujo, RC; Abdalla, AL; Vitti D, MSS (2010) Effect of phosphorus supplementation on gas production, rumen fermentation and produced amylase and carboxymethyle cellulase activity, in vitro. Lucrări Ştiinţifice 53, 97-104.

Navarro-Villa, A; O'Brien, M; Lopez S; Boland, TM; O'Kiely, P (2011) Modifications of a gas production technique for assessing in vitro rumen methane production from feedstuffs. Anim Feed Sci Technol 166-167, pp. 163-174.

DOI:10.1016/j.anifeedsci.2011.04.064

Oh, BC; Choi, WC; Park, S; Kim, YO; Oh, TK (2004) Biochemical properties and substrate specificities of alkaline and histidine acid phytases. Applied Microbiology and Biotechnology 63, 362-372.

Parekh, S; Vinci, VA; Strobel, RJ (2000) Improvement of microbial strains and fermentation processes. Appl Microbiol Biotechnol 54, 287-301.

Punt, PJ; van Biezen, N; Conesa, A; Albers, A; Mangnus, J; van den Hondel, C (2002) Filamentous fungi as cell factories for heterologous protein production. Trends in Biotechnology 20, 200-206.

Rosenfelder-Kuon, P; Siegert, W; Rodehutscord, M (2019) Effect of microbial phytase supplementation on $\mathrm{P}$ digestibility in pigs: a meta-analysis, Archives of Animal Nutrition, 74 , $1-81$, DOI:10.1080/1745039X.2019.1687249

Salem, AZM; Gado, HM; Colombatto, DB; Elghandour, MMY (2013) Effect of exogenous enzymes on nutrient digestibility, ruminal fermentation and growth performance in beef steers. Livestock Science 154, 69-73.

Sampath, K T; Wood, C D; Prasad, C S (1995) Effect of urea and by-products on the in vitro fermentation of untreated and urea treated finger millet (Eleusine coracana) straw. J Sci Food Agric 67, 323-328. 
Shah, P; Bhavsar, K; Soni, SK; Khire, JM (2009) Strain improvement and up scaling of phytase production by Aspergillus niger NCIM 563 under submerged fermentation conditions. J Ind Microbiol Biotechnol 36, 373-380.

Shanklin, RK (2001) Effect of form and amount of phosphorus and phytase supplementation on phosphorus utilization by ruminants. Master thesis, Faculty of the Virginia Polytechnic Institute, State University, Blacksburg, Virginia.

Shieh, T R; Ware, J H (1968) Survey of microorganisms for the production of extracellular phytase. Appl Microbiol 16, 1348-1351.

Shivanna, GB; Govindarajulu, V (2009) Screening of asporogenic mutants of phytase-producing Aspergillus niger CFR - 335 strain. Microbial Ecology in Health and Disease 21, 57 64.
Singh, PK (2008) Significance of phytic acid and supplemental phytase in chicken nutrition: a review. World's Poultry Sci J 64, 553-580.

SPSS (2008) Statistical package for Social Sciences, Statistics for Windows, Version 17.0. Released 2008. Chicago, U.S.A.: SPSS Inc.

Ullah, AHJ; Phillippy, BQ (1994) Substrate selectivity in Aspergillus ficuum phytase and acid phosphatases using myo-inositol phosphates. Journal of Agricultural and Food Chemistry 42, 423-425.

Wodzinski, RJ; Ullah, AH (1996) Phytase. Advances in Applied Microbiology 42, 263-302.

Yang, WZ; Beauchemin, KA; Rode, LM (1999) Effects of an enzyme feed additive on extent of digestion and milk production of lactating dairy cows. J Dairy Sci 82, 391-397. 


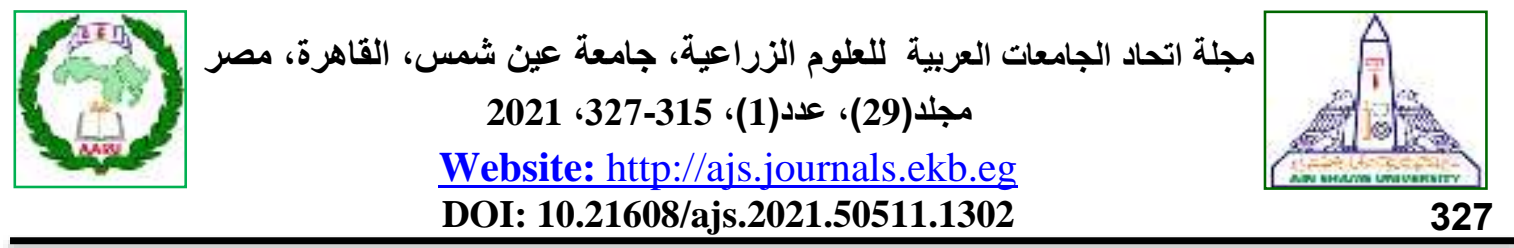

تحسين إنتاج إنزيم الفايتيز الفطري وتطبيقاته المعملية في تغذية الحيوانات المجترة

[20]

$$
\begin{aligned}
& \text { نهى عبد القادر حسان 1" - عبد الناصر عبد الحافظ خطاب2 - محمود محمد خورشيد3 - } \\
& \text { نصر السيد البرديني3 } 3
\end{aligned}
$$

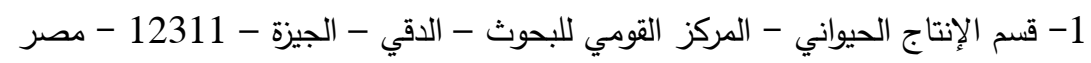

$$
\begin{aligned}
& \text { 2- قسم الوراثة وعلم الخلية - المركز القومي للبحوث - الدقي - الجيزة - } 12311 \text { - } 1230 \\
& \text { 3- قسم الانتاج الحيواني - كلية الزراعة - جامعة عين شمس - صع. بـ } 68 \text { - حدائق شبرا } 11241 \text { - القاهرة - مصر }
\end{aligned}
$$

*Corresponding author: noha_a_h@hotmail.com

المنتج معمليا (PE) مقارنة مع الفايتيز التجاري (AXta) على تحلل العناصر الغذائية لعلائق (Axtra® PHY)

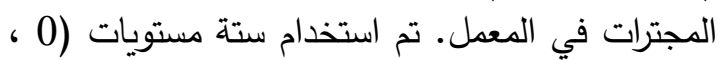

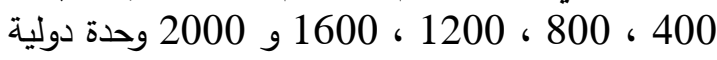

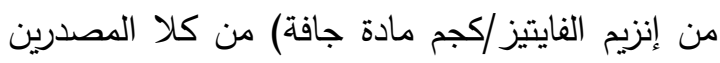

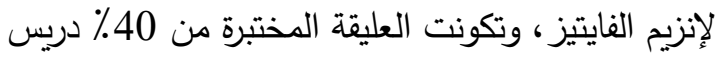

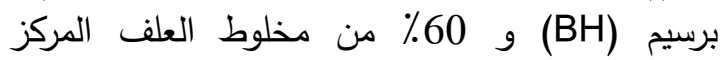
(CFM)

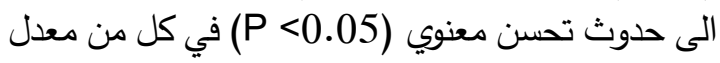
تحلل المادة الجافة والمادة العضوية معمليا (IVDMD)

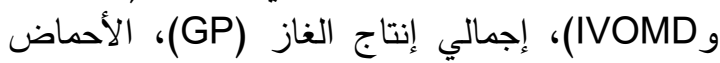
الدهنية قصيرة السلسلة (SCFA) وكذلك تركيز الفوسفور

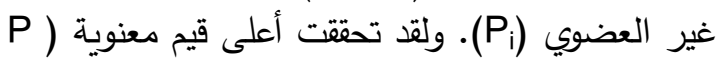

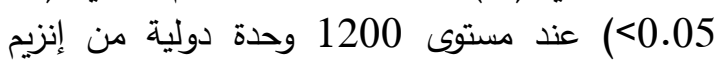
الفايتيز/كجم مادة جافة. وجد أن نشاط إنزيم الفايتيز يزداد

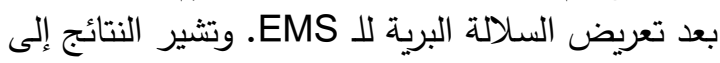

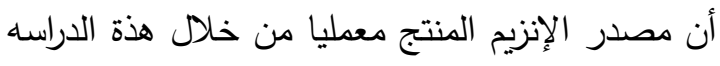

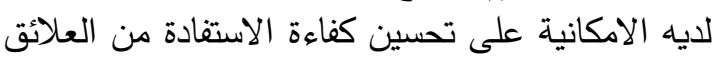

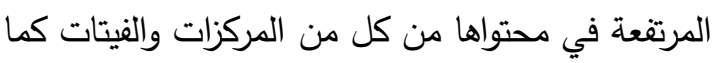

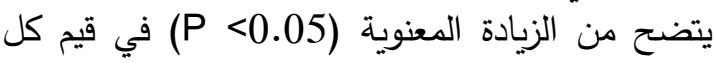
القياسات المختبرة عند مقارنته بمصدر الإنزيم التجاري.
تم فص العديد من السلالات الفطرية ،Aspergillus niger NRRL 3135 (AN1)) ،Aspergillus niger NRRL 326 (AN26) Mucor) و Aspergillus terrus F2-Kh (AT) racemosus NRRL 3639 (MI

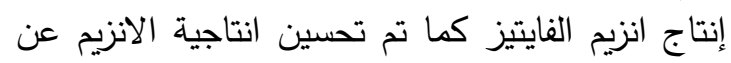

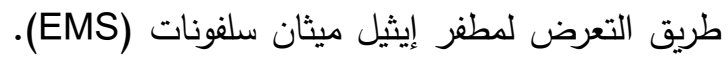
أظهرت السلالة AN1 أعلى نشاط للفايتيز بعد 8 أيام من التحضين (بلغ 1875.40 وحدة دولية/مل). زاد التئل

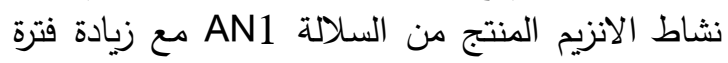
التحضين وتم تحقيق أعلى قيمة عند 12 يومًا من رنادين

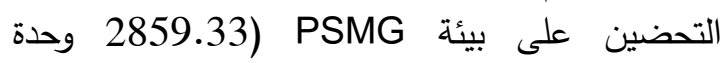

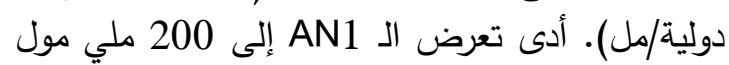
من مادة الـ EMS المطفرة لفترات زمنية مختلفة (20) و40 و 60 دقيقة) الى تحسين إنزيم الفايتيز، وأظهرت

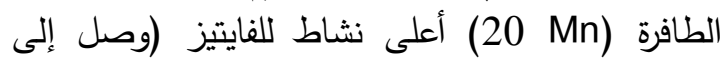

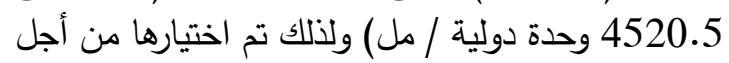

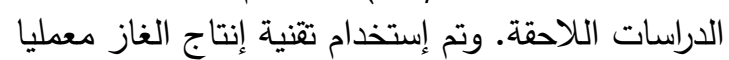
لتقييم تأثير استخدام مستويات مختلفة من إنزيم الفايتيز 